\title{
Atypical Radiologic Image Characterized by Cavitary Lung Lesions in a Case of Hodgkin Lymphoma
}

\author{
Hodgkin Lenfomalı Olguda Kaviter Akciğer Lezyonları ile Karakterize Atipik Radyolojik \\ Görüntü
}

\begin{abstract}
(D) Mahmut Büyükşimşek¹, (D) Semra Paydaş ${ }^{1}$, (D) Derya Gumurdulu², (D) Cem Mirili¹, (D) Ali Oğul1, (D) Abdullah Evren Yetişir1, (D) Mert Tohumcuoğlu1
\end{abstract}

${ }^{1}$ Çukurova University Faculty of Medicine, Department of Oncology, Adana, Turkey

${ }^{2}$ Çukurova University Faculty of Medicine, Department of Pathology, Adana, Turkey

\section{To the Editor,}

A 30-year-old woman was admitted to the hospital with a lump in her neck. She had no B symptoms (fever, night sweats, and weight loss) and a biopsy showed Hodgkin lymphoma ( $\mathrm{HL}$ ) of the classical type. Positron emission tomography/computed tomography (PET/CT) showed cervical and mediastinal lymph nodes of $1.5-3 \mathrm{~cm}$ in diameter and an invasive left parasternal mass of $4 \times 2.5 \mathrm{~cm}$.

Three cycles of ABVD (doxorubicin, bleomycin, vinblastine, dacarbazine) were given and less than partial response (PR) was detected by PET/CT. Salvage chemotherapy and autologous stem cell transplantation (ASCT) were planned and 2 cycles of the DHAP regimen (cisplatin, dexamethasone, cytosine) were given. PR was detected by PET-CT, but she rejected the ASCT. Local radiotherapy was given for the residual tumor. After radiation there was no evidence of a tumor upon PET/CT imaging. One and a half years after the end of radiation she was admitted with cough, dyspnea, sputum, and fever.

Thoracic CT showed cavitary lesions in the parenchyma of both lungs and atelectasis in the left lingula (Figure 1). The patient was counseled in the department of chest diseases; radiation pneumonia was not considered. The angiotensin-converting enzyme level for sarcoidosis was normal. Bronchoscopic examination, lavage, and biopsy were done. Fungal tests were found to be negative. The cavitary lesion was preferred for biopsy. The biopsy showed HL of the classical type (Figure 2) and CD30 was positive (Figure 3). A QuantiFERON test of the blood sample and tuberculosis polymerase chain reaction from biopsy material were negative.

$\mathrm{HL}$ is not a leading diagnostic consideration when evaluating cavitary lung lesions. An extensive differential diagnosis includes vasculitis, infection, and malignancy [1]. Parenchymal lung involvement is not uncommon in $\mathrm{HL}$; however, cavitary pulmonary lesions are quite unusual. Lung involvement in lymphoma is generally seen as nodule formation or consolidation.
Bronchoscopic evaluation is very important in these cases $[2,3]$. Disseminated cavitary lesions mimicking tuberculosis or other opportunistic infections in a case of HL is interesting and differential diagnosis is very important.

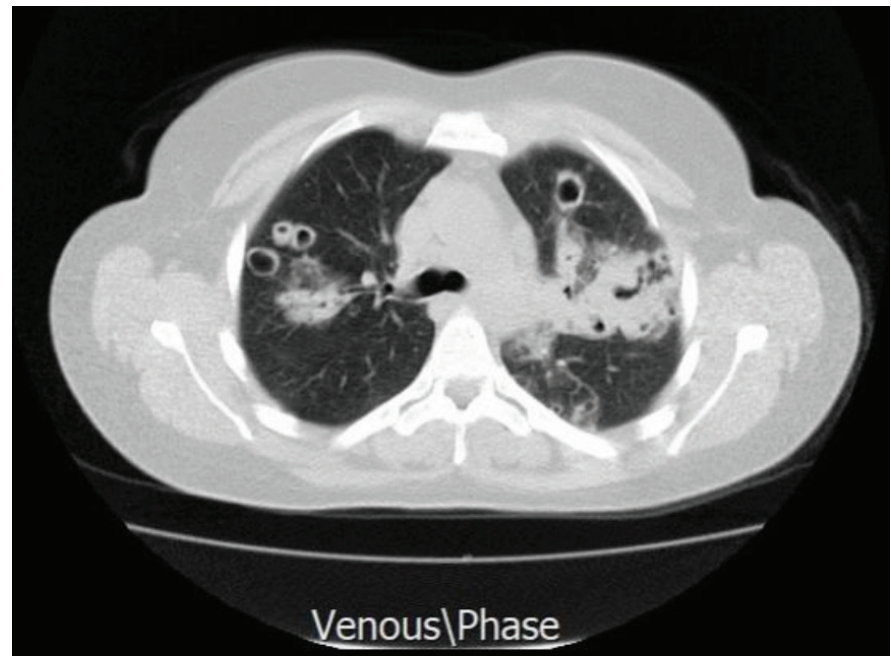

Figure 1. Cavitary pulmonary lesions and atelectasis in the left lingula.

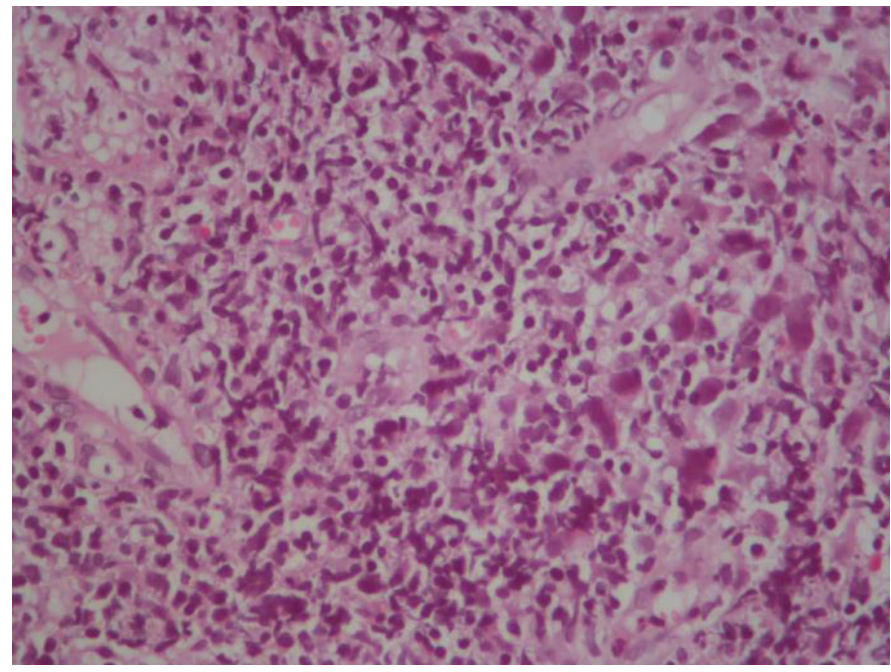

Figure 2. Bronchoscopic biopsy: Hodgkin lymphoma-classical type (H\&E, 200x). 


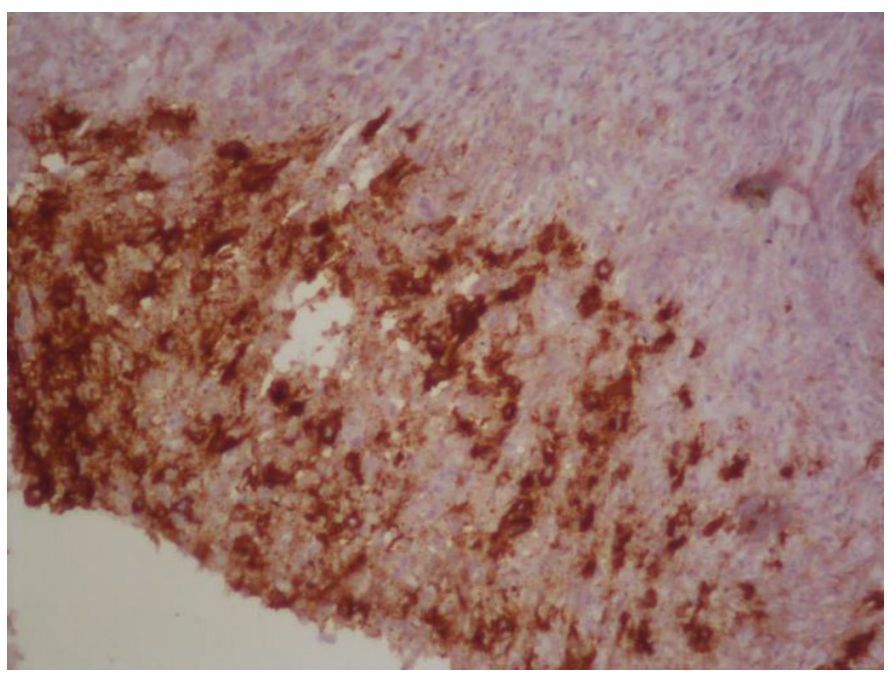

Figure 3. Bronchoscopic biopsy: Hodgkin lymphoma, CD30+.

Keywords: Hodgkin lymphoma, Cavitary lung lesions, Tuberculosis
Anahtar Sözcükler: Hodgkin lenfoma, Kaviter akciğer lezyonları, Tüberküloz

Informed Consent: It was received.

Conflict of Interest: The authors of this paper have no conflicts of interest, including specific financial interests, relationships, and/or affiliations relevant to the subject matter or materials included.

\section{References}

1. Grunzke $M$, Hayes $K$, Bourland W, Garrington T. Diffuse cavitary lung lesions. Pediatr Radiol 2010;40:215-218.

2. Bieliauskas S, Reyes-Trocchia A, Krasan GP, Main C, Trupiano JK. Hodgkin lymphoma presenting as multiple cavitary pulmonary nodules with associated mediastinal adenopathy and neck mass. J Pediatr Hematol Oncol 2009;31:730-733.

3. Yalçin B, Kutluk MT, Sanal O, Akyüz C, Anadol D, Cağlar M, Göçmen A, Büyükpamukçu $M$. Hodgkin's disease and ataxia telangiectasia with pulmonary cavities. Pediatr Pulmonol 2002;33:399-403.

\title{
Light Chain Myeloma with Highly Atypical Plasma Cells and Extensive Auer Rod-Like Inclusions
}

\author{
Yüksek Atipik Plazma Hücreleri ve Yaygın Auer Cisimciği Benzeri Innklüzyonları Olan Hafif \\ Zincir Myeloma
}

\author{
(D) Dietmar Enko1,2, (D) Gernot Kriegshäuser1,2 \\ 1 General Hospital Steyr, Institute of Clinical Chemistry and Laboratory Medicine, Steyr, Austria \\ 2 Medical University Graz, Clinical Institute of Medical and Chemical Laboratory Diagnostics, Graz, Austria
}

To the Editor,

A 73-year-old woman with a history of chronic kidney disease presented with fever $\left(39.8{ }^{\circ} \mathrm{C}\right)$, dyspnea, and fatigue. Complete blood count showed moderate normocytic anemia with hemoglobin of $10.0 \mathrm{~g} / \mathrm{dL}$ (normal range: 12.0-16.0), mild leukocytosis of 10.8×109/L (normal range: 4.0-9.0), and thrombocytopenia of 102×109/L (normal range: 150-400). Serum protein electrophoresis showed mild hypogammaglobulinemia of $6.7 \mathrm{~g} / \mathrm{L}$ (normal range: 7.0-16.0). Serum immunofixation electrophoresis demonstrated monoclonal $\kappa$-type light chains without heavy chain correlates ( $\lg G, \lg M, \lg A, \lg \mathrm{D}, \lg \mathrm{E})$. Moreover, a serum-free light chain assay measured a high $\kappa$-type light chain level of $2060.0 \mathrm{mg} / \mathrm{L}$ (normal range: 3.3-19.4) with a $\kappa / \lambda$ ratio of 48.5 (normal range: $0.3-1.7$ ).

A bone marrow aspirate smear showed $40 \%$ plasma cells, many of which appeared as binuclear plasmablastic cells with nucleoli ("owl-eyed" plasma cells), bright cytoplasm, and bundles of numerous Auer rod-like cytoplasmic inclusions (Figures $1 \mathrm{~A}$ and $1 \mathrm{~B})$. This unique morphology is remarkable. While the current literature describes Auer rod-like inclusions in single cases of different forms of myeloma $[1,2,3,4,5]$, this is, to the best of our knowledge, the first report on the concomitant appearance with enlarged highly atypical "owl-eyed" plasma cells in a patient suffering from $\kappa$-type light chain myeloma. 